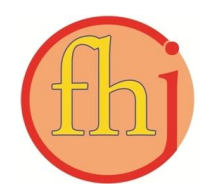

Faletehan Health Journal, 7 (1) (2020) 30-36

www. journal.Ippm-stikesfa.ac.id/ojs/index.php/FHJ

ISSN 2088-673X | e-ISSN 2597-8667

\title{
Pengaruh Perilaku Merokok, Konsumsi Alkohol dan Hiburan Malam Terhadap Risiko Penggunaan Narkotika
}

\author{
Akhmad Azmiardi ${ }^{*}$ \\ ${ }^{1}$ M agister IImu Kesehatan M asyarakat, Universitas Sebelas M aret, Surakarta \\ *Corresponding Author: aazmiardi@gmail.com
}

\begin{abstract}
Abstrak
Penyalahgunaan narkotika pada usia remaja terus meningkat setiap tahunnya. masuknya narkotika di Kalangan Siswa Sekolah Menengah Atas hingga kini hampir tidak bisa dicegah karena ancaman, hambatan dan gangguan di luar sekolah mengintai setiap saat, seperti bahaya merokok, minuman keras, tempat hiburan malam. Tujuan penelitian ini untuk mengetahui hubungan perilaku merokok, konsumsi alkohol dan hiburan malam terhadap risiko menggunakan narkotika. Penelitian ini merupakan penelitian cross sectional dengan responden sebanyak 278 siswa yang diambil dengan teknik proportional random sampling. Variabel dependen dalam penelitian ini adalah risiko penggunaan narkotika sedangkan variabel independen dalam penelitian ini antara lain perilaku rokok, konsumsi alkohol, dan hiburan malam. Instrumen penelitian menggunakan kuesioner dan analisis data menggunakan uji Chi-Square. Hasil penelitian menemukan bahwa adanya hubungan antara Perilaku merokok, perilaku minum-minuman alkohol dan perilaku mengunjungi tempat hiburan malam terhadap risiko penggunaan narkotika $(p=\measuredangle 0.001)$. Diperlukan regulasi yang baik untuk mengatur peredaran rokok, minuman beralkohol dan pembatasan usia pengunjung hiburan malam untuk mengurangi risiko penggunaan narkotika.
\end{abstract}

Kata Kunci: Alkohol, Narkotika, Remaja, Rokok

\section{Effects of Smoking Behavior, Alcohol Consumption and Night Entertainment Against the Risk of Narcotics Use}

\begin{abstract}
Drug abuse in adolescence continues to increase every year. the entry of narcotics among high school students until now has been almost unavoidable because of threats, obstacles, and disturbances outside of school lurking all the time, such as the dangers of smoking, liquor, nightclubs. The purpose of this study was to determine the relationship between smoking behavior, alcohol consumption and night entertainment on the risks of using narcotics. This research is a cross-sectional study with 278 students taken by a proportional random sampling technique. The dependent variable in this study is the risk of narcotics use while the independent variables in this study include cigarette behavior, alcohol consumption, and night entertainment. Research instruments using questionnaires and data analysis using the Chi-Square test. The results found that there was a relationship between smoking behavior, drinking alcoholic behavior and the behavior of visiting night entertainment venues to the risk of narcotics use $(p=<0.001)$. Good regulations are needed to regulate the circulation of cigarettes, alcoholic drinks and age restrictions on visitors of night entertainment to reduce the risk of narcotics use.
\end{abstract}

Keywords: Alcohol, Cigarettes, Narcotics, Teenagers 
Faletehan Health Journal, 7 (1) (2020) 30-36

www. journal.Ippm-stikesfa.ac.id/ojs/index.php/FHJ

ISSN 2088-673X | 2597-8667

\section{Pendahuluan}

Masa remaja adalah masa transisi dari masa kanak-kanak ke dewasa, ditandai dengan upaya untuk mencapai tujuan yang terkait dengan harapan budaya, serta persyaratan pembangunan fisik, mental, emosional, dan sosial. Masa Remaja memiliki karakteristik sendiri dalam hal biologis, psikologis, dan sosial, dengan proses pembentukan identitas, perkembangan sosial, dan norma-norma moral perilaku (McCabe, Veliz, Wilens, \& Schulenberg, 2017). Remaja adalah periode pengaturan yang hebat di mana eksperimen dengan zat psikoaktif adalah umum dan dapat, dalam beberapa kasus, mengarah pada pengembangan perilaku adiktif jangka panjang (Jeannin, Peyret, Bouche-Florin, Stehelin, \& Reyre, 2013). Narkotija adalah zat psikoaktif yang dapat merubah susunan kimiawi saraf di otak menyebabkan perubahan rasa, perubahan perilaku dan menimbulkan ketergantungan. Narkotika atau zat psikoaktif adalah termasuk obat obatan bersifat psikoaktif yang dijual bebas, dijual dengan resep, atau pun yang terlarang. Dextrometorpan dan Codein merupakan obat yang dijual dengan resep dan terkontrol, sementara ganja, kokain, heroin, dietergamid lisergik (LSD), crack, dan ekstasi adalah obatobatan terlarang (Kassa, Taddesse, \& Yilma, 2014). Penggunaan zat di kalangan remaja masih merupakan masalah utama di seluruh dunia yang menghasilkan banyak konsekuensi kesehatan dan ekonomi (Gutierrez \& Sher, 2015).

Penggunaan narkotika dan obat-obatan terlarang (narkoba) di kalangan remaja dinilai memprihatinkan. World Drug Report 2017 menyatakan sekitar 255 juta penduduk dunia berusia 15-64 tahun merupakan penyalahguna narkoba dengan estimasi global kematian terkait narkoba sejumlah 207.400 jiwa pertahunnya (UN, 2017). Tidak hanya itu, angka pengguna narkoba di Ibu Kota DKI Jakarta, juga terbilang tinggi. Berdasarkan data Badan Narkotika Nasional (BNN) $2.2 \%$ dari total populasi orang di Indonesia terjerat narkoba. Hal itu berdasarkan hasil penelitian terbaru BNN dan Universitas Indonesia (UI) yang menemukan bahwa terdapat sekitar 500 ribu penduduk yang terlibat dalam penyalahgunaan obat-obatan terlarang di Provinsi Jawa Tengah. Sedangkan, penggunaan narkoba di wilayah DKI Jakarta mencapai angka $7 \%$ dan merupakan angka tertinggi dibandingkan dengan kota lain. Kota lain rata-rata hanya berada pada angka 2,2\% pengguna dari jumlah penduduknya, selisih 4.8\% dibandingkan dengan Jakarta (Amanda \& Humaedi, 2017 ).

Penggunaan narkotika pada remaja menimbulkan masalah yang berhubungan dengan sekolah, seperti prestasi kelas yang buruk dan ketidakhadiran yang tinggi dari sekolah, dan prestasi kelas yang buruk telah ditemukan sebagai prediktor kuat untuk putus sekolah (Janosz, LeBlanc, Boulerice, \& Tremblay, 1997). Sebuah studi oleh Perini dan Marti (2011) menemukan bahwa penggunaan narkoba tidak memiliki efek langsung pada drop-out, tetapi memiliki dampak tidak langsung melalui hasil antara nilai buruk dan ketidakhadiran di sekolah. Dengan kata lain, masalah terkait sekolah jangka pendek nampaknya merupakan mediator penting antara penggunaan narkoba dan hasil negatif terkait sekolah jangka panjang. Oleh karena itu, penyelidikan tentang bagaimana masalah terkait narkoba dikaitkan dengan nilai yang buruk dan ketidakhadiran di sekolah menengah mungkin merupakan langkah penting menuju pemahaman yang lebih baik tentang remaja yang berisiko untuk hasil jangka panjang yang berhubungan dengan sekolah negatif yang lebih lama.

Sebuah studi menunjukkan bahwa siswa yang merasa putus sekolah mungkin menggunakan narkoba sebagai cara ikatan dengan siswa lain yang juga terputus dari sekolah (Fletcher, Bonell, Sorhaindo, \& Strange, 2009). Alasan lain mungkin karena lingkungan sekolah mungkin dianggap dan dirasakan terlalu menantang (dari kinerja sekolah hingga penerimaan kelompok), dan kesulitan untuk berprestasi dengan baik di lingkungan ini dapat menimbulkan frustrasi dan gejala emosional. Siswa mungkin menggunakan obat-obatan untuk mengurangi beberapa gejala ini atau melarikan diri dari tekanan sekolah. Sepengetahuan kami, belum ada penelitian sebelumnya dari Amerika Latin yang mengeksplorasi hubungan ini dan efek mediasi potensial dari gejala depresi atau kecemasan. Tujuan utama dari penelitian ini adalah untuk mengeksplorasi hubungan antara perilaku rokok, konsumsi alkohol, dan hiburan malam dengan risiko penggunaan narkotika pada Siswa Sekolah Menengah Atas. 


\section{Metode Penelitian}

Penelitian ini menggunakan desain survey analitik dengan pedekatan studi Cross Sectional. Penelitian ini dilaksanakan di sebuah Sekolah Menengah Atas di kota Singkawang yang memiliki siswa sebanyak 1008 orang. Pengambilan sampel menggunakan teknik purposive random sampling dengan jumlah sampel sebanyak 278 siswa. Variable dependen dalam penelitian ini adalah risiko penggunaan narkotika sedangkan variabel independen dalam penelitian ini antara lain perilaku rokok, konsumsi alkohol, dan hiburan malam. Instrumen didalam penelitian ini menggunakan kuisioner yang telah di uji validitas dan reabilitas, sedangkan risiko penggunaan narkotika menggunakan instrumen Alcohol, Smoking and Substance Involvement Screening Test (ASSIST) versi bahasa indonesia. Analisis data hasil penelitian menggunakan uji chi square.

\section{Hasil dan Pembahasan \\ Karakteristik Responden}

Umur responden hampir setengahnya berada pada usia 17 tahun yaitu; berjumlah 133 siswa (47.8\%), dengan jenis kelamin hampir keseluruhnya adalah laki-laki 258 siswa (92.8\%). Sebagian besar responden yaitu; 196 siswa (70.5\%) masih tinggal dengan orang tua, dengan status perkawinan orang tua sebagian besar masih terikat perkawinan sebanyak 243 siswa $(87.4 \%)$. Berdasarkan jenis pekerjaan hampir setengahnya memiliki ayah yang berkerja di bidang swasta yaitu berjumlah 116 siswa (41.7\%), dan memiliki Ibu yang hampir setengahnya beprofesi sebagai Ibu rumah tangga yaitu 136 siswa (48.9\%). Berdasarkan tingkat pendidikan orang tua, hampir setengahnya memiliki ayah tamatan setingkat SMA yaitu 122 siswa (43.9\%) dan hampir setengahnya memiliki Ibu tamatan setingkat SD yaitu 119 siswa (42.8\%).

Pada tabel 2, pada perilaku merokok, sebagian besar siswa menjawab "Ya" yaitu sebanyak 172 siswa (61.5\%) sisanya hampir setengah dari siswa tersebut menjawab "Tidak" yaitu sebanyak 107 siswa (38.5\%). Pada perilaku mengunjungi tempat hiburan malam hampir setengah siswa menjawab "Ya" yaitu sebanyak 135 siswa (48.6\%), dan sisanya sebagian besar siswa menjawab "Tidak" yaitu 143 siswa (51.4\%). Terakhir perilaku minum-minuman beralkohol, hampir setengahnya siswa menjawab
"Ya" yaitu berjumlah 106 siswa (38.1\%) dan sisanya sebagian besar siswa menjawab "Tidak" yaitu berjumlah 172 siswa (61.9\%).

Berdasarkan tabel 3, hasil analisis tingkat risiko penggunaan narkotika hanya sebagian kecil siswa saja yang berisiko menggunakan narkotika yaitu sebanyak 49 siswa (17.6\%) dan sisanya hampir seluruhnya tidak berisiko menggunakan narkotika yaitu 229 siswa (82.4\%).

Tabel 1. Karakteristik Responden

\begin{tabular}{|c|c|c|}
\hline Karakteristik & $\mathbf{N}$ & $\%$ \\
\hline \multicolumn{3}{|l|}{ Umur } \\
\hline 16 Tahun & 50 & 18 \\
\hline 17 Tahun & 133 & 47,8 \\
\hline 18 Tahun & 78 & 28,1 \\
\hline 19 Tahun & 14 & 5 \\
\hline 20 Tahun & 3 & 1,1 \\
\hline \multicolumn{3}{|l|}{ Jenis Kelamin } \\
\hline Laki-laki & 258 & 92,8 \\
\hline Perempuan & 20 & 7,2 \\
\hline \multicolumn{3}{|l|}{ Jenis Tempat Tinggal } \\
\hline Dengan orang tua & 196 & 70,5 \\
\hline Dengan Saudara & 41 & 14,7 \\
\hline Kost/Kontrak & 41 & 14,7 \\
\hline \multicolumn{3}{|l|}{$\begin{array}{l}\text { Status Perkawinan Orang } \\
\text { Tua }\end{array}$} \\
\hline Menikah & 243 & 87.4 \\
\hline Janda/Duda cerai meninggal & 11 & 4 \\
\hline Janda/Duda cerai hidup & 16 & 5.8 \\
\hline Lain-lain & 8 & 2.9 \\
\hline \multicolumn{3}{|l|}{ Pekerjaan Ayah } \\
\hline PNS & 22 & 7.9 \\
\hline Wiraswasta & 49 & 17.6 \\
\hline Swasta & 116 & 41.7 \\
\hline Petani & 91 & 32.7 \\
\hline \multicolumn{3}{|l|}{ Pekerjaan Ibu } \\
\hline PNS & 22 & 7.9 \\
\hline Wiraswasta & 17 & 6.1 \\
\hline Swasta & 34 & 12.2 \\
\hline Petani & 69 & 24.8 \\
\hline IRT & 136 & 48.9 \\
\hline
\end{tabular}


Faletehan Health Journal, 7 (1) (2020) 30-36 www. journal.Ippm-stikesfa.ac.id/ojs/index.php/FHJ ISSN 2088-673X | 2597-8667

\section{Analisis Bivariat}

Berdasarkan tabel 4, sebanyak 48 dari 171 siswa yang merokok yang juga memiliki risiko menggunakan narkotika. Sebaliknya hanya 1 dari 107 siswa yang tidak merokok yang memiliki risiko menggunakan narkotika. Hasil analisis diperoleh nilai Odds Ratio OR=41.34; CI 95\%= 5.61 hingga 81.21 ; nilai $p$ value $<0.001$ artinya perilaku merokok merupakan perilaku berisiko terhadap terjadinya peningkatan risiko penggunaan narkotika. Terdapat hubungan yang bermakna antara perilaku merokok dengan tingkat risiko penggunaan narkotika.

Sebanyak 48 dari 135 siswa yang mengunjungi tempat hiburan malam yang juga memiliki risiko menggunakan narkotika. Sedangkan hanya 1 dari 143 siswa yang tidak mengunjungi tempat hiburan malam yang memiliki risiko menggunakan narkotika. Hasil analisis diperoleh nilai $\mathrm{OR}=58.11$; CI $95 \%=$ 10.62 hingga 78.34 ; nilai $p<0.001$. artinya perilaku mengunjungi tempat hiburan malam merupakan perilaku berisiko terhadap terjadinya peningkatan risiko penggunaan narkotika. Terdapat hubungan yang bermakna antara perilaku mengunjungi tempat hiburan malam dengan tingkat risiko penggunaan narkotika.

Selanjutnya sebanyak 48 dari 106 siswa dengan perilaku mengkonsumsi minum-minuman beralkohol yang memiliki risiko menggunakan narkotika. Sedangkan hanya 1 dari 172 siswa yang tidak mengkonsumsi minum-minuman beralkohol yang memiliki risiko menggunakan narkotika. Hasil analisis diperoleh $\mathrm{OR}=86.89$; $\mathrm{CI}$
$95 \%=19.10$ hingga 90.26 ; dengan nilai $p<0.001$ artinya perilaku minum-minuman beralkohol merupakan perilaku berisiko terhadap terjadinya peningkatan risiko penggunaan narkotika. Terdapat hubungan yang bermakna antara perilaku minum-minuman beralkohol dengan tingkat risiko penggunaan narkotika

Tabel 2. Distribusi Frekuensi Perilaku Berisiko pada Responden

\begin{tabular}{lcc}
\hline Variabel Perilaku & N & $\%$ \\
\hline Merokok & 171 & 61.5 \\
$\quad$ Ya & 107 & 38.5 \\
$\quad$ Tidak & & \\
Mengunjungi hiburan malam & 135 & 48.6 \\
$\quad$ Ya & 143 & 51.4 \\
$\quad$ Tidak & & \\
Minum minuman beralkohol & 106 & 38.1 \\
$\quad$ Ya & 172 & 61.9 \\
$\quad$ Tidak & & \\
\hline
\end{tabular}

Tabel 3. Gambaran Risiko Penggunaan Narkotika pada Responden

\begin{tabular}{|c|c|c|}
\hline Risiko Penggunaan Narkotika & $\mathbf{N}$ & $\%$ \\
\hline Berisiko & 49 & 17.7 \\
\hline Tidak & 229 & 82.3 \\
\hline Jumlah & 278 & 100 \\
\hline
\end{tabular}

Tabel 4. Hasil Uji Statistik Perilaku Berisiko yang Mempengaruhi Risiko Penggunaan Narkotika

\begin{tabular}{|c|c|c|c|c|c|c|c|}
\hline \multirow{3}{*}{ Variabel } & \multicolumn{4}{|c|}{ Risiko Penggunaan Narkotika } & \multirow{3}{*}{ OR } & \multirow{3}{*}{$95 \% \mathrm{CI}$} & \multirow{3}{*}{$p$} \\
\hline & \multicolumn{2}{|c|}{ Berisiko } & \multicolumn{2}{|c|}{ Tidak Berisiko } & & & \\
\hline & $\mathbf{n}$ & $\%$ & $\mathbf{n}$ & $\%$ & & & \\
\hline \multicolumn{8}{|l|}{ Perilaku merokok } \\
\hline $\mathrm{Ya}$ & 48 & 28.1 & 123 & 71.9 & 41.34 & $5.614-81.21$ & $<0.001$ \\
\hline Tidak & 1 & 0.9 & 106 & 99.1 & & & \\
\hline \multicolumn{8}{|c|}{$\begin{array}{l}\text { Perilaku mengunjungi } \\
\text { tempat hiburan malam }\end{array}$} \\
\hline Ya & 48 & 35.6 & 87 & 64.4 & 58.11 & $10.62-78.34$ & $<0.001$ \\
\hline Tidak & 1 & 0.7 & 142 & 99.3 & & & \\
\hline \multicolumn{8}{|c|}{$\begin{array}{l}\text { Perilaku minum-minuman } \\
\text { beralkohol }\end{array}$} \\
\hline $\mathrm{Ya}$ & 48 & 45.3 & 58 & 54.7 & 86.89 & $19.10-90.26$ & $<0.001$ \\
\hline Tidak & 1 & 0.6 & 171 & 99.4 & & & \\
\hline
\end{tabular}




\section{Pembahasan \\ Hubungan antara Perilaku Merokok dengan Tingkat Risiko Penggunaan Narkotika}

Berdasarkan tabel bivariat terlihat hasil uji statistik Chi-square diperoleh $p<0.001$ yang menunjukan ada hubungan antara antara perilaku merokok dengan tingkat risiko penggunaan narkotika. Perilaku merokok akan berisiko 41 kali lebih tinggi meningkatnya risiko menggunakan narkotika dibanding dengan seseorang yang tidak merokok.

Modelling (meniru perilaku orang lain) menjadi salah satu determinan dalam memulai perilaku merokok, setelah mencoba rokok pertama, seorang individu menjadi ketagihan merokok, dengan alasan-alasan seperti kebiasaan, menurunkan kecemasan, dan mendapatkan penerimaan. Perilaku merokok pada remaja umumnya semakin lama akan semakin meningkat sesuai dengan tahap perkembangannya yang ditandai dengan meningkatnya frekuensi dan intensitas merokok, dan sering mengakibatkan mereka mengalami ketergantungan nikotin. Efek dari merokok hanya meredakan kecemasan selama efek dari nikotin masih ada, malah ketergantungan nikotin dapat membuat seseorang menjadi tambah stres pada remaja (Siswono \& Lestari, 2015).

Menjadi perhatian bagi orang tua yang merokok agar tidak merokok didepan anak sehingga tidak menjadi contoh yang salah, sekolah dapat melakukan razia rutin untuk mengecek siswa yang merokok serta melakukan penyuluhan rutin melalui diskusi dan pemutaran video industri rokok dan bahayanya bagi para remaja baik di sekolah.

Ada tiga teori terkait hubungan merokok dengan penyalahgunaan ganja. Teori ini dikaitkan dengan identifikasi individu rentan yang lebih tinggi risikonya untuk mengalami transit ke tipe zat illicit (terlarang) lainnya, seperti ganja. Teori pertama adalah hipotesis "the gateway" (GW). GW menyatakan bahwa perkembangan konsumsi zat adiktif mengikuti sebuah proses yang berurutan. Menurut hipotesis ini, penyalahgunaan ganja merupakan proses lanjut dari kebiasaan mengkonsumsi zat licit (tidak terlarang), seperti tembakau dan atau alkohol. Selanjutnya, penyalahgunaan ganja yang merupakan zat illicit kategori soft drug kemudian akan diikuti oleh konsumsi zat illicit dengan kategori hard drug, seperti kokain atau heroin (Van Leeuwen, Verhulst, Reijneveld, Vollebergh, \& Ormel, 2011).

Teori kedua adalah "the common liability" (CL). Teori CL menyatakan bahwa konsumsi zat baik licit maupun illicit dipengaruhi oleh genetik dan kerentanan individu, seperti kerawanan individu untuk melakukan penyimpangan dan kondisi keluarga yang mengalami ketergantungan. Tidak seperti teori GW, teori CL menyatakan bahwa (a) "pilihan" zat apa yang dikonsumsi pertama kali dipengaruhi oleh faktor-faktor tersebut di atas, yaitu genetik dan kerentanan individu; (b) Tidak ada urutan dalam proses perkembangan penyalahgunaan zat (Van Leeuwen, Verhulst, Reijneveld, Vollebergh, \& Ormel, 2011).

Teori ketiga adalah "route of administration" atau ROA. Teori ROA ini menduga bahwa teknik dari zat adiktif yang digunakan (misalnya dengan cara inhalasi atau dihisap) akan mempengaruhi tipe zat adiktif yang akan dikonsumsi atau disalahgunakan kemudian. Hal inilah yang memberikan penjelasan mengapa rokok dan ganja seringkali digunakan bersamaan atau coexist. Contohnya, pelajar/mahasiswa yang merokok lebih mungkin untuk menyalahgunakan ganja di kemudian karena ganja memiliki tipe yang mirip dengan rokok, yaitu diisap atau diinhalasi (Van Leeuwen, Verhulst, Reijneveld, Vollebergh, \& Ormel, 2011).

\section{Hubungan antara Perilaku Mengunjungi Tempat Hiburan Malam dengan Tingkat Risiko Penggunaan Narkotika}

Pada uji stastistik Chi-square diperoleh $p<0.001$ yang menunjukan ada hubungan antara perilaku mengunjungi tempat hiburan malam dengan tingkat risiko penggunaan narkotika. Perilaku mengunjungi tempat hiburan malam akan berisiko 58 kali lebih tinggi meningkatnya risiko menggunakan narkotika dibanding dengan seseorang yang tidak mengunjungi tempat hiburan malam.

Penelitian Ismail (2017) menemukan beberapa alasan mahasiswa-mahasiswi datang ke tempat hiburan malam atau diskotik, ajakan dari teman dan rasa penasaran merupakan faktor utama mengapa seorang clubbers melakukan kegiatan dugem Adanya perasaan tidak enak atau ketidak setia kawanan ketika diajak oleh teman yang 
Faletehan Health Journal, 7 (1) (2020) 30-36

www. journal.Ippm-stikesfa.ac.id/ojs/index.php/FHJ

ISSN 2088-673X | 2597-8667

membuat seseorang ikut bergabung untuk menikmati hiburan malam (Ismail, 2017). Selain ajakan dari teman faktor lain yang menyebabkan mahasiswa mengunjungi tempat hiburan malam adalah untuk mendapatkan rasa senang dan menghilangkan beban pikiran. Para informan mengaku mengunjungi diskotik untuk bersenangsenang untuk menghilangkan beban.

Rasa senang merupakan tujuan utama bagi mereka yang ingin mencari hiburan dan melepas kepenatan di tempattempat hiburan malam. Selain rasa senang, faktor lain yang menyebabkan mahasiswa gemar mengunjungi tempat hiburan malam adalah karena ingin dianggap gaul atau rasa gengsi yang muncul dalam dirinya. Gaul merupakan sebuah istilah yang dikenal sebagai sesuatu yang jika tidak dilakukan maka perdikat "gaul" tersebut tidak bisa dipandang atau hal yang menjadi ciri anak muda yang populer sehingga disebut sebagai "anak gaul”. Maka untuk menjadi populer citra yang melekat adalah hal-hal yang berbau glamor atau menjadi bagian dari efek budaya global

Faktor lain yang menyebabkan mahasiswa gemar mengunjungi tempat hiburan malam adalah karena rasa jenuh (Ismail, 2017). Setiap manusia pasti akan merasakan kejenuhan dalam hidupnya dan akan membutuhkan hiburan guna menghilangkan kejenuhan tersebut. Hal ini juga terjadi pada clubers yang biasa melakukan dugem. Salah satu alasan yang sering dikemukakan clubber tentang mengapa mereka dugem adalah untuk menghilangkan jenuh dan menyelesaikan permasalahan. Para clubber umumnya beralasan bahwa mereka melakukan dugem dikarenakan memerlukan hiburan setelah melakukan berbagai aktivitas sehari penuh. Bagi para clubber melakukan dugem adalah salah satu cara menghilangkan kejenuhan yang dirasakan dalam kehidupan sehari-hari. Kebutuhan ekonomi juga merupakan salah satu alasan keterlibatan mahasiswa ke tempat hiburan malam.

Menurut BNN salah satu tempat rawan peredaran narkotika adalah tempat hiburan malam. Tempat-tempat hiburan malam tersebut kerap kali menjadi tempat tujuan berkumpulnya para pengguna dan pengedar Narkotika. Hal ini dapat dilihat dari kegiatan razia yang dilakukan di tempat-tempat hiburan malam selalu di dapati narkotika diantara pengunjung maupun oknum hiburan malam dan banyak pengunjung yang dinyatakan positif mengonsumsi Narkotika. Ini mengindikasikan bahwa tempat hiburan malam menjadi tempat bagi berkumpulnya pengguna dan pengedar (BNN, Laporan Akhir Survei Nasional Perkembangan Penyalahguna Narkoba Tahun Anggaran 2014, 2014).

Saat ini para remaja dengan mudahnya keluar masuk cafe, diskotik, club, tempat karaoke, dan sejenisnya. Pembatasan umur untuk masuk tempat hiburan dan kurang ketatnya peraturan di tempat hiburan tersebut membuat remaja gampang berlalu lalang. Pemerintah harus mengkaji ulang akan masalah ini, agar anak muda generasi bangsa bisa menjadi penerus bangsa yang berkompeten dan terbebas dari narkotika.

\section{Hubungan Perilaku Minum-Minuman Beralkohol dengan Tingkat Risiko Penggunaan Narkotika}

Berdasarkan tabel bivariat terlihat hasil uji statistik Chi-square diperoleh $p<0.001$ yang menunjukan ada hubungan antara perilaku minum-minuman beralkohol dengan tingkat risiko penggunaan narkotika. perilaku minum-minuman beralkohol akan berisiko 86 kali lebih tinggi meningkatnya risiko menggunakan narkotika dibanding dengan seseorang yang tidak minumminuman beralkohol.

Konsumsi alkohol merupakan awal mula seseorang terlibat dalam penyalahgunaan zat yang lebih berat seperti narkotika (Gunawan, 2009). Alkohol menimbulkan gejala euforia dan tidak ada rasa segan, sehingga menyebabkan seseorang mabuk. Jika konsumsi minuman beralkohol dihentikan, maka akan menimbulkan sindrom putus alkohol, yang akan membuat seseorang mencari dan menambah dosis/takaran dan semakin sering mengonsumsinya.

Minum alkohol merupakan perilaku yang mendukung seseorang untuk mengkonsumsi narkotika. Menurut Sitorus (2016) bahwa pengguna narkotika sebelumnya memiliki kebiasaan minum alkohol yaitu sebesar $76 \%$, memiliki kebiasaan minum alkohol sampai mabuk sebesar $51.3 \%$, usia pertama kali menggunakan narkotika $\leq 20$ tahun sebesar $65.3 \%$ dan frekuensi minum alkohol jarang sebesar $42.7 \%$. Mengkonsumsi alkohol mempunyai korelasi negatif dengan kualitas hidup. Alkohol dapat mengganggu kinerja, kecerdasan, mengubah fungsi kognitif, menjadikan orang emosional dan berpengaruh terhadap kehidupan sosial. Keracunan alkohol juga mengganggu indeks 
neurofisiologi dan domain psikomotorik (Sitorus, 2016).

\section{Simpulan}

Hasil penelitian menunjukan perilaku berisiko yang mempengaruhi tingkat risiko penggunaan narkotika yaitu perilaku merokok, perilaku mengunjungi tempat hiburan malam dan perilaku minum-minuman beralkohol. Maraknya peredaran minuman beralkohol sekarang ini menjadi awal timbulanya masalah di kalangan remaja seperti tawuran dan narkotika, diperlukan adanya regulasi pengaturan dan pelarangan penjualan rokok dan minuman beralkohol secara bebas serta memperketat batasan usia pengunjung hiburan malam.

\section{Referensi}

Amanda, M., \& Humaedi, S. S. (2017 ). Penyalahgunaan Narkoba Di Kalangan Remaja. Jurnal Penelitian \& PPM, 4(2), 129389. doi:DOI:10.24198 /jppm.v4i2.14392

BNN. (2011). Peran Orang Tua Terhadap Anak Dalam Pencegahan Penyalahguna Narkotika Dan Prekursor Narkotika Sejak Dini. Jakarta: Badan Narkotika Nasional.

BNN. (2013). Laporan Data Pengguna Narkoba di Kalimantan Barat. Badan Narkotika Nasional Provinsi Kalbar.

BNN. (2014). Laporan Akhir Survei Nasional Perkembangan Penyalahguna Narkoba Tahun Anggaran 2014. Jakarta: Badan Narkotika Nasional.

Fletcher, A., Bonell, C., Sorhaindo, A., \& Strange, V. (2009). How might schools influence young people's drug use? Development of theory from qualitative case-study research. $J$ Adolesc Health., $\quad 45(2), \quad$ 126-32. doi:10.1016/j.jadohealth.2008.12.021

Gunawan, W. (2009). Keren Tanpa Narkoba. Jakarta: Grasindo.

Gutierrez, A., \& Sher, L. (2015). Alcohol and drug use among adolescents: an educational overview. Int J Adolesc Med Health, 27(2), 207-212. doi:10.1515/ijamh-2015-5013.

Ismail. (2017). Diskotik Dan Mahasiswa Kajian Sosiologi Pada Penikmat Hiburan Malam Di Kota Makassar. Makassar: Pendidikan Sosiologi Program Pascasarjana. Universitas Negeri Makassar.

Janosz, M., LeBlanc, M., Boulerice, B., \& Tremblay, R. E. (1997). Disentangling the weight of school dropout predictors: a test on two longitudinal samples. J. Youth Adolesc., 26, 733-762. doi:10.1023/A:1022300826371

Jeannin, R., Peyret, E., Bouche-Florin, L., Stehelin, A., \& Reyre, A. (2013). Adolescents and young adults in situations of addiction. Soins Pediatr. Pueric, 27-31.

Kassa, A., Taddesse, F., \& Yilma, A. (2014). Prevalence and factors determining psychoactive substance (PAS) use among Hawassa University (HU) undergraduate students, Hawassa Ethiopia. BMC Public Health, 14, 1044-1051. doi:10.1186/14712458-14-1044

McCabe, S. E., Veliz, P., Wilens, T. E., \& Schulenberg, J. E. (2017). Adolescents' prescription stimulant use and adult functional outcomes: a national prospective study. J. Am. Acad. Child Adolesc. Psychiatry, 56, 226.e4233.e4. doi:10.1016/j.jaac.2016

Silva, A., Lucchese, R., Vargas, L., Benício, P., \& Vera, I. (2016). Application of the Alcohol, Smoking and Substance Involvement Screening Test (ASSIST) instrument: an integrative review. Rev Gaucha Enferm, 37(1), e52918. doi:10.1590/19831447.2016.01.52918.

Siswono, E., \& Lestari, D. (2015). Penyuluhan Pengenalan Bahaya Merokok, Minuman Keras, Dan Narkoba Pada Siswa Tingkat SdSmp Kecamatan Campaka Kabupaten Purwakarta Jawa Barat. Diambil kembali dari https://doi.org/10.21009/sarwahita.121.07

Sitorus, R. (2016). Penggunaan Narkotika Mendukung Perilaku-Perilaku Berisiko. Jurnal Ilmu Kesehatan Masyarakat, 7(1), 1-5. Diambil kembali dari https://doi.org/10.26553/jikm.2016.7.1.1-5

UN. (2017). World Drug Report . New York: United Nations.

Van Leeuwen, A., Verhulst, F., Reijneveld, S., Vollebergh, W., \& Ormel, J. H. (2011). Can the gateway hypothesis, the common liability model and/or, the route of administration model predict initiation of cannabis use during adolescence? A survival analysis - the TRAILS studi. Journal of Adolescent Health, 48, 73 - 78. Diambil kembali dari https://doi.org/10.1016/j.jadohealth.2010.05.00 8 